Наталя ЧЕРКАШИНА, orcid.org/0000-0003-3972-0817 аспірантка

Національної академії керівних кадрів культури і мистецฺтв, головний судовий експерт Харківського науково-дослідного експертно-криміналістичного ијентру Міністерства внутрішніх справ України (Харків, Україна) cherkashinatalya@gmail.com

\title{
ГОЛЛАНДСЬКІ МИСТЕЦЬКІ СОЮЗИ ТА ЇХНІЙ ВПЛИВ НА РОЗВИТОК ГРАФІЧНОГО МИСТЕЦТВА КРӒ̈НИ
}

\begin{abstract}
У статті досліджено вплив об'єднань художників на розвиток та популяризацію графічних робіт XVIIХІХ ст. на прикладі збірки голландської графіки з колекиії Харківського художнього музею. Базуючись на небагатих архівних матеріалах та публікаціях мистецтввознавців та істориків, у статті висвітлені специифіка найбільш відомих голландських художніх союзів: Гільдія Святого Луки, «За мистецттво і дружбу» та «Майстерня Пулькрі». Тема діяльності товариства «Голландська графічна компанія» практично відсутня у міжнародних дослідженнях, тому можна припустити, щчо ичя асоиіація відійшла на другий план, оскільки в той час значний вплив на розвиток голландського мистецтвв мали та існують нині асоиіації «За мистецтво $і$ дружбу» та «Майстерня Пулькрі». У публікачії визначені основні характеристики громад митщів, головні правила та регламенти, розкрито шляхи надходження коштів для організаиії виставок. Хоча всі товариства відрізнялись одне від одного, вони були подібними в оцінцฺі художника за його талантом, технічною майстерністю, а не за обраним ним мистеиьким напрямом.
\end{abstract}

Проаналізовано характер і динаміку зміни константного методу відтворення реальності «по пам'яті» до малювання з натури та початку практики роботи на пленері. Процеси просування графічного мистецтва та становлення колекціонування акварельних творів висвітлено в нерозривному зв'язку зі створенням мережі спілок художників.

Незважаючи на не завжди сприятливі історичні передумови, в Україні існують колекиії, зобов'язані своїм походженням шанувальникам графічного мистеитва. На прикладі дослідження колекиії голландської графіки, яка міститься у складі фонду Харківського художнього музею, було доведено, шчо на сьогодні не існує спеціального історичного, техніко-стилістичного вивчення та мистецтвознавчого аналізу иієї збірки. Водночас спеціальні комплексні дослідження подібних збірок є закономірним та необхідним процесом, зокрема для всесвітньої популяризаиії культурної спадщчини України.

Ключові слова: Харківський художній музей, графіка Голландї, мистецькі спілки.

Natalia CHERKASHYNA,
orcid.org/0000-0003-3972-0817

Postgraduate Student

National Academy of Culture and Arts Management, Chief Forensic Expert Kharkiv Scientific Research Forensic Center of the Ministry of Internal Affairs Ukraine (Kharkiv, Ukraine) cherkashinatalya@gmail.com

\section{DUTCH ART UNIONS AND THEIR INFLUENCE ON THE DEVELOPMENT OF GRAPHIC ART OF THE COUNTRY}

The article explores the influence of associations of artists on the development and popularization of graphic works of the XVII-XIX centuries using the example of a collection of Dutch graphics from the collection of the Kharkiv Art Museum. Based on the poor archival materials and publications of art critics and historians, the article highlights the specifics of the most well-known Dutch art unions: "the Guild of Saint Luke", "Arti et Amicitiae" and "Pulchri Studio". There is practically no information about the "Hollandsche Teekenmaatschappij" in international studies, so it can be assumed that this association has been sidelined, because, since at that time the associations "Arti et Amicitiae" and "Pulchri Studio" had a significant influence on the development of Dutch art and exist till now. The publication defines the main characteristics of the grooms of artists, the main rules and regulations, and reveals the ways of receiving funds for organizing exhibitions. Although all societies differed from each other, they were similar in assessing the artist in his talent, technical skill, and not in the artistic direction he chooses. 
The nature and dynamics of the change of constant method of reproduction of reality "from memory" to drawing from nature and the beginning of practice of working on plein-air are analyzed. The processes of promotion of graphic art and development of watercolor works collection are illuminated in an inextricable connection with the creation of a network of artists'unions.

Despite not always favorable historical prerequisites, there are collections in Ukraine, which owe their origin to fans of graphic art. An example of a study of the Dutch graphics collection, which is contained in the Kharkiv Art Museum's foundation, proved that there is no special historical, technical-stylistic study and art historical analysis of this collection. At the same time, special comprehensive studies of such collections are a logical and necessary process, in particular for the worldwide popularization of the cultural heritage of Ukraine.

Key words: Kharkiv Art Museum, Dutch Graphic Arts, art unions.

Постановка проблеми. Атрибуція та дослідження художніх колекцій неможлива без детального вивчення історичних, релігійних, побутових, соціальних аспектів життя та філософських, наукових уявлень певної нації, які висвітлюють особливості світогляду суспільства та завжди мають відображення у творах мистецтва. Зазвичай зміни у суспільстві породжують і зміни у культурі, які, своєю чергою, призводять до виникнення нових сюжетів та художніх технік. Вивчення цих аспектів приводить до кращого і всебічного розуміння робіт, дозволяє здійснити докладний мистецтвознавчий аналіз пам'яток образотворчого мистецтва досліджуваного періоду. Детальне дослідження творчої діяльності та буденного життя представників мистецьких професій дає можливість виявити та оцінити головні надбання, внесок у світове мистецтво, зрозуміти, що слугувало основою для пошуку та розвитку, вдосконалення культури тогочасного суспільства.

Використання акварелі має давню традицію, яка налічує століття. Акварель виконувала різноманітні функції: у цій техніці оформлені численні книги, ботанічні атласи, топографічні карти, а також виконані мініатюрні портрети.

Рисунки художників всіх мистецьких шкіл, окрім того, що завжди слугували джерелом вивчення реального світу через сприйняття об'єму та простору, але ще й відкривали цінувальникам, як рисунок може «оголити» задумку майстра. Рисунки голландської школи, незважаючи на те, що вони згодом були визнані шедеврами світового мистецтва, не завжди були об'єктами грунтовного та комплексного сучасного дослідження. Збірка Харківського художнього музею дає можливість дослідити принципи вирішення сюжетів, особливості стилістики та технічного виконання графічних робіт голландської школи, зміни, які відбувалися під впливом часу та різноманітних мистецьких течій.

Аналіз досліджень. Результати досліджень зарубіжних науковців і мистецтвознавців дають змогу доповнити відомості про графічні роботи голландських художників 3 колекції Харківського художнього музею. Вплив на розвиток мистецтва графіки сторонніх чинників та факторів досліджений у розвідках таких авторів, як Саскія де Бодт, Кріс Столвейк, Едді де Йонг, Тон ван Калмтут, присвячених життю, творам митців та виникненню ранніх художніх об'єднань, починаючи 3 епохи Просвітництва до XIX ст. Існує також цілий ряд монографій загального характеру, серед яких праці Джонатана Ізраельса, який пропонує вичерпний та інтегрований матеріал досліджень $\mathrm{i}$ роздумів, що збирались протягом 12 років та сповнені цікавими деталями про Нідерланди практично за 350 років. Пітер Хечт, використовуючи порівняльний метод, дав характеристику символізму в голландському мистецтві XVII ст. через звернення до процесів у тогочасному суспільстві. Однак, на теперішній час не існує техніко-стилістичного чи мистецтвознавчого аналізу збірки голландської графіки з колекції Харківського художнього музею, попри те, що у 1991 році збірка була виставлена в Тафському художньому музеї.

Мета статті - проаналізувати роль культурних, історичних та суспільних впливів на формування і зміну художніх особливостей вирішень сюжетів та технічні удосконалення, впроваджені нідерландськими майстрами акварельного живопису на прикладі збірки графічних творів Харківського художнього музею, дослідити існування різноманітних мистецьких колаборацій Голландії XVII-XIX ст.

Виклад основного матеріалу. У Нідерландах XVII ст. виділялися місцеві центри, де існували об'єднання художників. Таким центром був Амстердам, а його лідером на певний час став Рембрандт. Місцем народження Рембрандта та батьківщиною Ван Гойєна був Лейден, що також перетворився на один зі значних центрів мистецького розвитку. Гаага стала осередком спілок художників, але Гаарлем був не менш відомим, ймовірно, через привілеї, які надавала митцям Гільдія Святого Луки - покровителя живописців, створена в цьому місті. Гільдія Святого Луки в Гаарлемі залишила цінні історичні записи - можливо, не завжди вони є першоджерелами, але, без- 
умовно, достовірні за походженням. Вони дають змогу доторкнутися до витоків нідерландського мистецтва.

Ближче до кінця XVII ст. Вінсент Лоренс ван дер Вінне склав список зі 174 осіб, які в його час були визнані гарними художниками, і яких він особисто знав. Його син у 1702 р. доповнив цей список, позначивши літерою «d» тих художників, які померли до його батька, тож у переліку залишилось тільки шістнадцять імен. Онук В. Л. ван дер Вінне, володіючи манускриптами та бухгалтерськими книгами попереднього періоду, мав можливість розширити список ранніх членів Гільдії і додати до відомих фактів тогочасні закони Гільдії. «Ніхто без відома Гільдії не міг продати або представити на виставці свої роботи. Багато живописців, таким чином, були вимушені вступити до Братства, щоб користуватися його перевагами. Щороку, два великих продажі оголошувались від імені Гільдії; кожен учасник міг приносити на продаж все, що він хотів би продати» (Davies, 1987: 150). Певна кількість художників була залучена 3 інших міст - хтось на невеликий термін, а хтось на більш тривалий час, адже «Не всі жили у Гаарлемі» (Davies, 1987: 148).

Незважаючи на привілеї, які надавала Гільдія, для багатьох професія художника не була прибутковою. Навіть найбільш завантажені і плодовиті художники, як, наприклад, Філіп Вауерман, іноді були боржниками своїм друзям. Інші були настільки бідні, що їм навіть списували щорічні членські внески до каси Гільдії.

Національне життя Голландії, протягом цього насиченого століття піддавалось багатьом змінам смаків та тенденцій, які впливали навіть на високе мистецтво. Голландська школа, яка в XVII ст. була провідною у європейському мистецтві, була першою, хто повною мірою відчув цінність тих безпосередніх вражень, котрі міг відтворити рисунок. В той же час італійці та фламандці визнавали, головним чином, цінність рисунка тільки для подальшого удосконалення та деталізації майбутньої живописної роботи. Майстри Голландії, навпаки, прагнули увічнити у графічних аркушах враження, які, можливо, були швидкоплинними, але не менш яскравими.

Саме упродовж XVII ст. у Нідерландах рисунки почали колекціонувати та замовляти для особистих цілей, на відміну від більш традиційної їхньої функції як підготовчої роботи - ескізу або начерку. У цей час в рисунках з'являються різноманітні сюжети, подібні на сюжети у живописних творах, тож поступово ескіз став не тільки етапом виконання роботи, а й завершеним об'єктом, готовим для подальшого продажу. Наприклад, пейзажні рисунки Ван Евердінгена, послідовника Ван Гойена, і Молейна майже всі були підписані, часто датовані і виконані як самостійні роботи, призначені для продажу.

У літературі $з$ мистецтва XVII ст. зазвичай обговорюються дві важливі концепції, які можуть бути пов'язані з методом виконання графічного твору: рисунок "near het leven" («від життя», тобто з натури), чи "uyt den geest” («по пам'яті»). У XVI ст. ці два методи були пов'язані між собою темою релігійної або міфологічної сцени, зображеної з уяви. Водночас, рисунок може бути оснований на роботі 3 живою моделлю та постійній практиці удосконалення майстерності художника в процесі такої діяльності. Протягом XVII ст. концепція створення зображення «з натури» набула більшого значення, адже й рисунки «по пам'яті» часто формувалися через роботу з натурою.

Більшість голландських художників-пейзажистів подорожували, якщо не за кордон, то принаймні, близькими околицями, і часто малювали в сільській місцевості або мали ескізні книги, всі вони вміли гарно малювати і по пам'яті. Задокументовано, що Рембрандт здійснював прогулянки навколо Амстердаму та робив замальовки міста та його околиць. Повернувшись до майстерні, художник міг перегрупувати природні об'єкти, щоб створити найдостовірніше зображення за обраною тематикою. Ван Гоєн подорожував не менше за Рогмана, а їхні роботи, хоча й більш сучасні, так само як і роботи Рембрандта, зберігають колорит рідних для них місць. Пізніший період, сповнений подорожами закордон та контактами 3 мистецтвом інших країн, суттєво відмінним, привніс у графіку голландців нові методи та інше розуміння ідеалу.

Так, під значним впливом своїх попередників, 3 одного боку, та натхненні іноземними інноваціями $з$ іншого боку, художники Гааги у XVII ст. широко почали практикувати роботу на пленері та заохочували до цього художників-початківців. Художники пейзажу, як правило, подавали не саму реальність, а правдоподібний вигляд голландського оточення, заснований на малюванні «3 натури» в поєднанні з методом «по пам'яті». Таким чином, іноді важко відрізнити рисунки, що робилися «3 натури», від тих, що виконували «по пам'яті» - але саме це поєднання відрізняло роботи цього періоду.

Аналогічним чином, рисунок з колекції Харківського художнього музею (надалі ХХМ) «Приємна жінка за бочкою» Германа Сафтлевенамолодшого і «Натюрморт» на якому зображено 
маленьку валізу, ранець, відро, капелюх, чашка та блюдце, виконаний анонімним автором. Ймовірно, обидві роботи починались як ескізи з уяви, але здаються виконаними з найвищою мірою натуралістичності, оскільки малювання «по пам'яті» бере початок від малювання «з натури». Обидва твори вказують на значну роль, яку рисунок відіграв у формуванні реалістичних рис нідерландського мистецтва XVII ст.

Протягом XVIII ст. значення рисунка, як самостійної галузі мистецтва, продовжувало зростати. Інтерес колекціонерів до графічних копій картин XVII ст. зумовив необхідність додавання до них кольору, а любов збирачів до докладних та деталізованих робіт надавало кольоровому рисунку більшої ваги. Виготовлення копій і додавання кольору в репродукції створювали додатковий дохід для багатьох художників. «Художник-пейзажист та рисувальник Ісаак де Мушерон, для задоволення попиту на кольорові та закінчені роботи, зробив основним видом своєї діяльності саме створення копій та репродукцій, іноді додаючи колір і свій підпис до оригінальних пейзажів XVII ст., але частіше виконуючи власні акварельні твори. Дірк Maec, який працював у XVII-XVIII ст., випускав кольорові рисунки високого рівня технічної майстерності, на яких були зображені коні та італійські пейзажі» (Slive, 1998: 184).

Незважаючи на те, що у XXМ представлено лише кілька графічних творів XVIII ст., протягом цього періоду значення рисунку залишалось незмінним, оскільки вважалося необхідним мати гарні навички рисувальника і для художників всіх інших видів просторового мистецтва. В результаті були створені численні безкоштовні школи малювання для навчання учнів усім художнім технікам.

Можна констатувати, що на початок XIX ст. ретельно виконаний, деталізований, кольоровий i закінчений рисунок залишався вибором колекціонерів, незважаючи на відсутність письмових доказів щодо популярності у збирачів XVIII-XIX ст. конкретних типів та стилів рисунка. В той же час акварелі, пастелі, гуаші та виконані в інших техніках ескізи підпадають під визначення начерків. Однак, згідно 3 коментарями художника і колекціонера XVIII ст. Корнеліса Плоса ван Амстела, до ескізу також зростав інтерес через його безпосередність у втіленні думок художника.

3 середини XIX ст. люди стали більше цінувати начерк і чорновий рисунок. Баренд Корнеліс Коеккоєк прокоментував необхідність для художника постійно замальовувати i досліджувати натуру у своїй роботі «Одкровення пейзажного художника», в той час як Вінсент Ван Гог підкрес- лив важливість постійного спостереження за природою, кожного разу відкриваючи для себе щось нове (Dumas, 2001: 24). Віллем Рулофс закликав художників використовувати природу як провідника і відображати враження від моменту. Антон Мауве рекомендував Ван Гогу вдосконалити акварельну техніку, щоб заробляти нею на життя. Протягом другої половини XIX ст. широкий попит на акварель залишався, це можна побачити на прикладі зібрання Аркадія Алфьорова і за відібраними ним для виставки творами: понад половина 3 тридцяти шести робіт виконані аквареллю.

Тим часом в Амстердамі товариство художників "Arti et Amicitiae" («За мистецтво і дружбу»), засноване 3 грудня 1839 р., пропагувало визнання акварелі і творів на папері, їхню популяризацію через художні виставки. Це найстарше товариство художників, де самі митці визначали політику, яка демонструє єдність у поєднанні з різноманітністю. Процедура вступу до товариства "Arti et Amicitiae" була досить складною, але дозволяла відібрати найкращих, а членство означало визнання високого рівня професійності художника.

«Правління було повністю у руках художників, які підтримували гарні відносини з заможними особами, що дозволяло "не художникам" та поціновувачам потрапити до товариства, щоб бути вписаними як учасники. Товариство “За мистецтво і дружбу" також організовувало зустрічіроздуми на художні теми, виставки, лекції, розіграші та затишні зустрічі. Особливістю було те, що для художників, які овдовіли, був створений "Уизерфонд" - фонд спеціального соціального забезпечення. Так, шляхом встановлення професійного статусу та покращення соціального становища товариства "За мистецтво та дружбу” було далеко попереду у другій половині XIX ст., на відміну від інших професійних асоціацій художників та організацій, які тільки лобіювали інтереси всіх фахівців Голландського мистецтва» (Stolwijk, 1998: 100-101).

У 1847 р. монопольне становище товариства "Arti et Amicitiae" було порушене створенням картинної студії молодих пейзажистів у Гаазі "Pulchri Studio" («Майстерня Пулькрі»), яка давала змогу своїм членам практикувати малювання 3 натури, обговорювати творчість один одного і надавала художникам місце для спілкування. Йоханнес Босбом та Віллем Рулофс були одними з перших членів, що приєдналися до неї.

«Різниця між консервативним «За мистецтво i дружбу» та прогресивною «Майстернею Пулькрі» була суттєвою, особливо у художніх принципах» (Bodt, 2004: 27-28). На відміну від «За 
мистецтво і дружбу», «Майстерня Пулькрі» була більш практичною за своїм характером та наближеною до природи. «Мета цієї Гаазької асоціації сприяння мистецтву та любов до художніх відображень» (Reglement van, 1847: 28). Проте, обидві організації прагнули ствердити спільну для них ідею аристократичності та підняття соціального статусу митців. «Відомі вечірки, організовані “Майстернею Пулькрі”, рекламували собою студію краще, аніж будь-яка афіша» (Bodt, 2004: 35).

Для того, щоб студія мала успіх та була процвітаючою, Генріх Віллем Месдаг поклав всі свої зусилля на ії розвиток. Крім того, зростала популярність Гааги та іï школи, що стало сприятливим фактором для поступу. Тим не менше, товариство "Arti et Amicitiae" доволі довгий час залишалось асоціацією провідних діячів мистецтва.

На відміну від товариства "Arti et Amicitiae", "Pulchri Studio" почала організовувати виставки сучасного мистецтва тільки наприкінці XIX ст. До того часу художники з Гааги у просуванні своїх робіт залежали від виставок у товаристві «За мистецтво і дружбу» або ж вуличних виставок. «З організацією виставок між асоціаціями художників посилилось суперництво. Таким чином, відстань між двома мистецькими містами Амстердамом та Гаагою збільшувалась» (Stolwijk, 1998: 165).

«За мистецтво і дружбу» та «Майстерня Пулькрі» були головними об'єднаннями художників, які надавали змогу поціновувачам мистецтва стати ближчими до художників, а художникам знайомити маси зі своєю творчістю через членство у вищезгаданих товариствах. Виставки були постійними та відкритими до різноманітних художніх проявів.

Окрім цих національних груп, у XIX ст. були створені також об'єднання, котрі акцентували свою діяльність на конкретному жанрі мистецтва. Таким прикладом стало створене у 1876 р. голландське рисувальне товариство, похідне від «Майстерні Пулькрі» - "De Hollandsche Teken Maatschappij” («Голландська графічна компанія»), яке також активно підтримувало ринок акварелей та створення якого було ініційоване саме художниками. Воно було засноване за зразком Бельгійського акварельного товариства, створеного в 1855 p., і більш давнього елітарного англійського акварельного товариства, яке існувало з 1804 р. Хендрик Віллем Месдаг взяв на себе відповідальність та обов'язки президента, а 27 березня 1876 р. було затверджено резолюцію, яка складалась 3 десяти положень. Відтепер, «Голландська графічна компанія» складалася 3 рядових та почесних членів. Усі нові кандидати були запропоновані правлінням, та право на голосування було відведено засновникам, якими були: Юліус Ван де Санде Бакхуйзен, Герардіна Якоба ван де Санде Бахуйзен, Христофел Бісхоп, Віллем Маріс, Антон Мауве, Якоб Маріс, Йозеф Ізраельс, Філіп Саде, Пітер Стортенбекер, Герке Хенкес, Йоханнес Босбом, Бернар Бломмерс, Давід Блес, Кєйт Біссхоп Свіфт. Якщо один із засновників йшов у відставку, його місце було займав рядовий член організації, але більшість місць залишалась за засновниками.

Членські внески були відсутні, проте, у випадку потенційної нестачі коштів для проведення виставки, рядові учасники несли рівнозначну фінансову відповідальність. Зазвичай, організація виставки обходилась асоціації у певну суму, тому було прийнято рішення, що десять відсотків від продажу кожного об'єкту під час виставки товариства «Голландська графічна компанія» йшло на користь фонду асоціації, а у випадку надлишку, суму відокремлювали для наступної виставки. Таким чином, асоціація мала можливість організовувати виставки у просторих приміщеннях за умови продажу достатньої кількості лотів на попередній виставці. Щоб впевнитись, що всі учасники товариства прихильні до успішного проведення виставки, кожен 3 них мав надати по одному своєму рисунку для кожної виставки. У 1883 р. ця кількість була збільшена до трьох творів, крім того, подавати роботи мали тільки рядові члени асоціації. 3 членів правління плата за участь та продаж робіт у виставках не знімалась.

Ще одним обов'язковим правилом для участі було попереднє внесення автора до списку учасників виставки. Залишалась одна фінальна задача: знайти відповідне місце для демонстрації акварельних робіт. Однак це не викликало жодних проблем, оскільки Королівська академія мистецтв у Гаазі на безоплатній основі надавала для показів зали у своїй будівлі.

Перша виставка товариства «Голландська графічна компанія», відбулась у серпні 1876 р., майже через два роки після його заснування. 3 цього часу відбувалася активна рекламна діяльність, щорічні виставки, до яких випускались каталоги та альбоми. Багато каталогів містять анотації, що дозволяє сьогодні отримати додаткову інформацію.

Протягом двох років низка художників - Геррі мет де Блес, Ельчанон Вервеер і Іохан Гендрік Вейсенбрух - були включені до складу «Голландська графічна компанія», і це вважалося безумовним успіхом товариства. Так залишалося до 1890-х рр., коли художники потрапили під сильну критику і попит на твори, виконані аквареллю, впав, порів- 
няно 3 інтересом до творів, що підкреслювали точність лінії. До речі, до теперішнього часу не існує жодних грунтовних наукових досліджень стосовно «Голландська графічна компанія», хоча розпад товариства стався тільки у $1921 \mathrm{p}$.

Завдяки присутності Віллема Рулофа в Брюсселі, голландські акварелі з їхньою майстерністю i точністю техніки були високо оцінені бельгійською публікою і колекціонерами. Там користувалися величезною популярністю роботи Геррі мет де Блеса, Йоханнеса Босбома, Йозефа Ізраельса та Антона Мауве.

Ескізи олією, аквареллю, крейдою, бістром та тростинним пером, офортною голкою - всі ці техніки в руках великих голландців були не просто вдосконаленим варіантом відомих художніх технік, а втілювалися у витончені, довершені роботи для своєї аудиторії, настільки ж виразні та цікаві, як робота олією, що потребувала більшого часу і була складнішою за виконанням. Техніка акварелі вважається однією з найскладніших, тому що допущені художником помилки не можна легко виправити. Тому барвистість кожного 3 таких закінчених ескізів не була важливою: 3 «великими» художниками кількість кольорів мала інше значення: вони знали, що важливішою справою $є$ достатність тоні для передачі отриманих автором вражень глядачу.

I це $є$ характерним для голландського мистецтва, особливо для голландського пейзажу, у якого не було періоду болючого становлення, в той час, як мистецтво інших шкіл повинно було довго боротися за свободу самовираження. 3 досвіду минулого і близького минулого митці, зокрема Брюгге і Лейдена, отримали метод створення виразного колірного вирішення, завжди економічного у засобах, але часто дуже швидкого та спрощеного. «Робота перших майстрів не має ні дріб'язковості маніпуляцій, коли вона найбільш делікатна, ні невизначеності, коли вона найбільш швидка. Ознаки мистецтва зрілого - екстремальна концентрація, рішення впевненої руки та, як результат, швидкий у виконанні, але шедевр» (Kalmthout, 1998: 64).

Висновки. Враховуючи вищевикладене, можна стверджувати, що починаючи з XVII ст., у Нідерландах було різноманітне суспільне життя у світі мистецтва. Особливим типом взаємодії художників були міждисциплінарні гільдії та товариства: «За мистецтво і дружбу», «Майстерні Пулькрі», «Голландська графічна компанія», в яких могли контактувати практикуючі професіонали та початківці або любителі образотворчого мистецтва. Головна ціль таких об'єднань полягала в тому, щоб навчити цінувати мистецькі прояви у приємній атмосфері та гарній компанії. Це була хвиля справжнього розквіту Голландії-час, в який Ван Гойєн малював у притаманній йому манері завжди вишукано, делікатно та різнобарвно, довгі береги річок, містечка у низині і широке високе голландське небо; час, в якому Антон Мауве загострював увагу на вигляді післяобідніх сонячних полів, які парують від теплого вологого повітря; в якому Петрус Герар Вертін майстерно зображав чарівність котеджів та вулиць при сонячному світлі, а Девід Йозеф Блес удосконалив захоплене і всеосяжне пізнання світу людей, яке коли-небудь проявлялося у мистецтві; і в якому Рембрандт із задоволенням зображував голландське життя i пейзажі, завжди з майже рівною силою виразності та художньою точністю.

Твори зазначених авторів зі збірки Харківського художнього музею $є$ відтворенням естетичних принципів та доказом майстерності, як відомих художників, так і тих, які залишились у тіні, особливо деяких представників заможної буржуазії, котрі, проте, також не менше заслуговують на окреме дослідження.

\section{СПИСОК ВИКОРИСТАНИХ ДЖЕРЕЛ}

1. Davies M. The Early Netherlandish School / National Gallery catalogues. London : The National Gallery, reprinted 1987. $207 \mathrm{p}$.

2. Kalmthout A.B.G.M. van. Muzentempels : multidisciplinaire kunstkringen in Nederland tussen 1880 en 1914. Hilversum, 1998. $776 \mathrm{p}$.

3. Stolwijk Ch. Uit de schilderswereld: Nederlandse kunstschilders in de tweede helft van de negentiende eeuw. Leiden, 1998. $416 \mathrm{p}$.

4. Bodt S. de. Brussel kunstenaarskolonie : Nederlandse schilders 1850-1890. Warnsveld, 2004. 160 p.

5. Reglement van het Schilderkunstig Genootschap Pulchri Studio. 1847. 19 februari. 1847. 28 p.

6. Haak B. The Golden Age : Dutch painters of the XVII century. London : Thames \& Hudson Ltd, 1984. $536 \mathrm{p}$.

7. Jongh E. de. Real Dutch life and not-so-real Dutch life: some nationalistic vews of XVII century Nederlandish painting. Simiolus. 1990/91. Vol. 20. P. 197-206.

8. Slive S. Dutch painting : 1600-1800. New Haven ; London, 1998. 392 p.

9. Israel J. The Dutch Republic. Its rise, greatness, and fall 1477-1806. Oxford, 1995. $1231 \mathrm{p}$.

10. Hecht P. The debate on symbol and meaning in Dutch seventeenth-century art: an appeal to common sense. Simiolus. 1986. Vol. 16. P. 173-187. 
11. Dumas C. Bibliografie van Nederlands onderzoek naar beeldende kunst en kunstnijverheid 1700-1900 door Nederlandse en in Nederland werkzame auteurs, gepubliceerd in de periode $1991 \mathrm{t} / \mathrm{m} 2000$ (18de eeuw) en $1996 \mathrm{t} / \mathrm{m} 2000$ (19de eeuw). Vereniging van Nederlandse Kunsthistorici. 2001. 171 p.

\section{REFERENCES}

1. Davies M. The Early Netherlandish School / National Gallery catalogues. London : The National Gallery, reprinted 1987. 207 p. [in English].

2. Kalmthout A.B.G.M. van. Muzentempels : multidisciplinaire kunstkringen in Nederland tussen 1880 en 1914. [Temples for muses: multidisciplinary artistic circles in the Netherlands between 1880 to 1914]. Hilversum, 1998. 776 p. [in Dutch].

3. Stolwijk Ch. Uit de schilderswereld: Nederlandse kunstschilders in de tweede helft van de negentiende eeuw. [From the world of painting: Dutch artists of the second half of the XIX century]. Leiden, 1998. 416 p. [in Dutch].

4. Bodt S. de. Brussel kunstenaarskolonie : Nederlandse schilders 1850-1890. [Brussels Artists' colony: Dutch Artists 1850-1890]. Warnsveld, 2004. 160 p. [in Dutch].

5. Reglement van het Schilderkunstig Genootschap Pulchri Studio. 1847. 19 februari. [Regulations art society Pulchri Studio. 1847. February 19]. 1847. 28 p. [in Dutch]. lish].

6. Haak B. The Golden Age : Dutch painters of the XVII century. London : Thames \& Hudson Ltd, 1984. 536 p. [in Eng-

7. Jongh E. de. Real Dutch life and not-so-real Dutch life: some nationalistic vews of XVII century Nederlandish painting. Simiolus. 1990/91. Vol. 20. P. 197-206. [in English].

8. Slive S. Dutch painting : 1600-1800. New Haven ; London, 1998. 392 p. [in English].

9. Israel J. The Dutch Republic. Its rise, greatness, and fall 1477-1806. Oxford, 1995. 1231 p. [in English].

10. Hecht P. The debate on symbol and meaning in Dutch seventeenth-century art: an appeal to common sense. Simiolus. 1986. Vol. 16. P. 173-187. [in English].

11. Dumas C. Bibliografie van Nederlands onderzoek naar beeldende kunst en kunstnijverheid 1700-1900 door Nederlandse en in Nederland werkzame auteurs, gepubliceerd in de periode $1991 \mathrm{t} / \mathrm{m} 2000$ (18de eeuw) en 1996 t/m 2000 (19de eeuw). [Bibliography of Dutch studies in the field of Dutch fine and applied arts from 1700-1900 by Dutch authors, published between 1991 and 2000 (18th century) and from 1996 to 2000 (19th century)]. Vereniging van Nederlandse Kunsthistorici. 2001. 171 p. [in Dutch]. 